Virtuous Power Turkey in Sub-Saharan Africa:

\title{
The 'Neo-Ottoman' Challenge to the European Union
}

\begin{abstract}
European officials veer towards exceptionalism in their policy communications concerning the EU's global role, particularly in terms of African development. This article poses a rejoinder to such tendencies through examination of the rise of 'Virtuous Power Turkey' in Africa. It examines how Turkish elites constructed a moralised 'neo-Ottoman' foreign policy in wake of stalled EU accession. It then underscores how elites framed humanitarian interventions in sub-Saharan Africa in contrast to the perceived neo-colonialism of an EU 'other'. In this vein, the article explores the meaning of normative 'neo-Ottomanism' for ostensible beneficiaries in Africa, for the EU, and for Turkey itself.
\end{abstract}

\section{Keywords}

Africa; Europe; Turkey; trade; development; norms; ethics; foreign policy; elites

Dr Mark Langan

Lecturer in International Politics

University of Leicester

Attenborough Tower

Leicester

LE1 7RH

Email: mcel1@leicester.ac.uk

Dr Mark Langan is Lecturer in International Politics at the University of Leicester. His research is particularly focussed on critical assessment of EU trade and development ties with sub-Saharan Africa, the Maghreb, and the Middle East. He recently authored a monograph (2016) on EUAfrica Association for Routledge. 
Wherever there is fire, wherever there is pain, Turkey has mobilised all means to extinguish that fire and has travelled great distances to heal those wounds... We will reach out to every corner of the world. ${ }^{1}$

European Union (EU) officials have veered towards 'exceptionalism' when communicating their policies towards countries of the Global South. In the case of EU relations with sub-Saharan Africa, for example, there is a long history of exceptionalist discourse. From the Schuman Declaration which launched Europe's 'essential task', to the 'spirit of Lome', to the 'pro-poor' Cotonou Agreement, EU officials have hailed Europe's special contribution to vulnerable peoples. ${ }^{2}$ Moreover, this sentiment has been mirrored in scholarly literature, notably in terms of Normative Power Europe. Many academics applying this concept have applauded the European Commission for attempts to improve wellbeing beyond Europe's borders. ${ }^{3}$ The EU is seen to act on ethical principle and to change partners' behaviour in alignment with cosmopolitan values. As Manners explains, the European project has a 'normatively different basis for its relations with the world' due to its history, 'hybrid policy' and 'constitutional configuration. ${ }^{4}$ Interestingly, while Manners himself has recently retreated from exceptionalism - following critiques by Diez and Storey, among others - nevertheless, a creeping exceptionalism remains present within many scholarly discussions on EU external relations. ${ }^{5}$

Wary of the conceits of EU exceptionalism, this article explores the much neglected image of so-called Virtuous Power Turkey. ${ }^{6}$ Regrettably the normative foreign policy identity of Turkey remains understudied, notwithstanding its 'MINT' status. The article underscores how Turkish elites have constructed a moralised discourse concerning their country's own international role in juxtaposition to the machinations of an 'imperial' EU. Importantly, this strategy is seen as an outgrowth of stalled EU accession. President Recep Tayyip Erdoğan and his erstwhile ally Ahmet Davutoğlu (the recent Prime Minister) launched a 'neo-Ottoman' foreign policy in wake of stalled EU accession talks in 2005. These Turkish leaders constructed a new 'personality' for the nation to guide its actions abroad. Importantly, this elite project was not merely a nationalist enterprise. It was a wholly normative enterprise, drawing upon Ottoman history to articulate a uniquely Turkish moral mission in global affairs. (Re)interpreting Ottoman history as one of benevolent hegemony, Erdoğan and his ministers have sought to construct an altruistic identify for modern Turkey. They have sought to emphasise shared cultural bonds as justifying Turkey's ethical mission in former Ottoman territories. Moreover, they have sought to emphasis the future impact of Turkey's 'virtuous power' beyond this traditional sphere. According to their elite discourse, Turkey seeks a truly global role based upon core humanitarian and altruistic principles.

With similarities to European exceptionalism, moreover, this Turkish discourse is particularly prevalent in the case of ties with the Global South. Accordingly, this article focuses upon relations between 'Virtuous Power Turkey' and countries of sub-Saharan Africa. Following on from the Turkish government's recent priorities, it pays closest attention to emerging links with Somalia. Importantly, however, Turkish interventions in this state are not seen as a 'one-off' but rather are viewed as a 'staging post' for wider forays. Indeed, as recently as June 2016 President Erdoğan embarked on a four day tour of East Africa, meeting with the leadership of Uganda and Kenya, in an attempt to extend Turkish influence. ${ }^{7}$ By examining Turkish interventions in sub-Saharan Africa, the article explores the normative terrain upon which the Erdoğan-Davutoğlu elite have justified the exercise of 'virtuous power'. Interventions in Africa, particularly in terms of Somalia after the 2011 famine, are seen as a crucial pillar upon which Erdoğan's Justice and Development Party (AKP) has sought to realise moral 
imperatives overseas. Applying a constructivist perspective allied to critical discourse analysis, however, the article juxtaposes such moral statements with the actual material outcomes of Turkish interventions for African citizenry. ${ }^{8}$ In so doing, the article problematizes certain ethical claims propounded by Erdoğan and his ministers. For example, Turkish interventions in Somalia to promote development are seen to have mixed results in terms of regressive forms of Turkish foreign direct investment (FDI). The provision of Turkish arms in sub-Saharan Africa more widely is also deemed questionable in terms of normative credentials.

Furthermore, the article considers the implications of recent Turkish interventions in Africa for debates surrounding Europe's global actorness, and for EU-Africa relations. The article makes clear that AKP elites have constructed Virtuous Power Turkey in juxtaposition with the regressive acts of a European 'other'. Turkish intervention in Africa is justified on the grounds that not only can Turkish personnel reach certain (Muslim) populations in 'fragile' countries where European officials fear to tread. But, that Turkey, by virtue of norms embedded in that nation, is a more trustworthy partner than the EU. In this context, the article argues that Turkey-Africa ties in the neo-Ottoman phase of Erdoğan's rule has significance for challenging EU moral credibility abroad, as well as for further complicating Turkey's own ambivalent (and increasingly hostile) relationship with Brussels.

The article is structured as follows. The first section explores this apparent neo-Ottoman turn through a social constructivist lens. The second section examines the discourse and material interventions of Virtuous Power Turkey in its dealings with sub-Saharan Africa. The third section questions certain outcomes of Turkish policy vis-à-vis 'ethical' objectives. It also explores the wider consequences of Virtuous Power Turkey's entreaties with African countries in terms of Europe's international standing, and EU-Africa affairs.

\section{Neo-Ottomanism and AKP elite constructions}

Secular elites of the Republican People's Party (CHP), and of past military regimes, constructed a Turkish global identity in conscious reference to their European neighbourhood. 'Kemalist' officials sought to portray Turkey as a modern country in a European mode that would abide by liberal precepts. In the Cold War setting, these Kemalists especially sought to emphasise their pro-Western credentials, aligning with the then European Economic Community (EEC) and the USA in matters of economics and defence. Turkey, in this context, was itself supported by Western partners as a moderate ally, one which possessed a particular geopolitical importance.

In the more recent era of AKP governments led by Recep Tayyip Erdoğan, however, Turkish elites have constructed a 'neo-Ottoman' foreign policy identity. This seeks to not only reassert Turkish influence in the historical Ottoman sphere of influence in the Balkans, the Middle East, and North Africa. But to more broadly reassert Turkish policy autonomy on a global level vis-à-vis Europe and the 'West'. This has largely come about as a consequence of the Erdoğan governments' frustration at the stalled EU accession process. The emergence of neo-Ottoman discourse acted as a salve to the embarrassment caused to AKP elites as a result of their earlier attempts to present a pro-European identity without much credit in terms of EU membership. As Rudincová makes clear:

The important factor in re-shaping and diversification of Turkish [foreign] policy can be seen in the rejective approach of the European Union (EU) towards Turkish admission... 
all these difficulties led to the decline in government support for the EU membership... and [it] started to search for another geopolitical alternative. ${ }^{9}$

This perspective is widely supported, for instance, by Robins who explains that the 'vaulting disdain' of certain EU states at accession negotiations in Luxembourg in October 2005 (combined to the collapse of the Annan Plan on the question of Cyprus) led to a breakdown in Turkish relations with Brussels. ${ }^{10}$ The view is also supported by expert officials, including (then) US Defence Secretary Robert Gates. Erdoğan himself, meanwhile, has regularly expressed grievance about how Turkey has been treated during, and after, the 2005 negotiations. ${ }^{11}$ In short, stalled accession has spurred AKP elites' foreign policy volte-face away from Eurocentrism towards a more autonomous path.

In a post-2005 timeframe, AKP officials thus began to discursively draw upon the Ottoman past to demarcate a distinctive Turkish foreign policy role from an EU 'other'. This sought not only to appeal to external partners beyond the EU but to cement domestic support for the AKP. Elites thus sought to build a new national image as part of both internal and external legitimation processes. It is useful here to reflect on the utility of a social constructivist lens for making sense of (and for critiquing) these processes. As Hill and Wallace remark:

effective foreign policy rests upon a shared sense of nationality identity, of a nation state's "place in the world", its friends and enemies, its interests and aspirations. These underlying assumptions are embedded in national history and myth, changing slowly over time as political leaders reinterpret them and external and internal developments reshape them. ${ }^{12}$

Foreign policy identities thus rest upon processes of social construction. Governing elites take a central role in formulating national-identity discourse to present their policy preferences as being legitimate (in normative terms) to internal and external audiences. Moreover, as Vertzberger makes clear, elites do not merely construct the nation via discourse - but they are themselves shaped by preexisting discourses. ${ }^{13}$ In the case of AKP elites, narratives of Ottoman history may influence their decision-making, as nationalist sentiment drives forward their action in the present day. In turn, these elites consciously utilise language that propels forward a neo-Ottoman vision of Turkish identity, and of foreign policy action. This is in keeping with the insights of critical discourse analysis that seeks to assess how discourse acts within society. Critical discourse analysts such as Wodak, Fairclough and van Djik all emphasise that discourse is constitutive. That is, individuals not merely construct dominant narratives, but that they too are shaped by language. ${ }^{14}$

Furthermore, elite discursive constructs do not take place in isolation from events but - as Hill and Wallace make clear (above) - take place in direct negotiation with historical processes (such as the stalling of EU accession in 2005) as well as material/strategic pressures (for instance, Turkish business desire to enter overseas markets). In this situation, elites utilise certain historical narratives to (re)define foreign policy roles. This bears resemblance to the arguments put forward by Benedict Anderson. As Anderson argues, the nation is constructed over time in negotiation with historical memory. ${ }^{15}$ And so too, can the nation's foreign policy evolve according to how elites may seek to reassert or downplay certain aspects of a national identity vis-à-vis their current policy preferences.

A constructivist lens allied to critical discourse analysis can help to explore the power purposes of certain narratives utilised by AKP elites in their attempts to usher in this neo-Ottoman role. Specifically, 'critical' discourse analysis seeks to understand how language might underpin power 
relations. This involves attention to potential injustices arising from certain discourses and power structures. As Fairclough et al make clear:

Since discourse is so socially influential, it gives rise to important issues of power... [discourse] can help produce and reproduce unequal power relations... [discourse] may try to pass off assumptions (often falsifying ones) about any aspect of social life as mere common sense. ${ }^{16}$

In the context of Turkish foreign policy, critical discourse analysis helps us to first consider how actions are presented as being 'legitimate', and second, to ask whether policy interventions abide (in terms of material impact) by normative credentials as articulated by governing elites.

When turning to AKP elites, a constructivist lens thus help us to make sense of Turkish foreign policy identity construction as undertaken by key figures such as Erdoğan and Davutoğlu. Analysis of elite statements indicates how a distinct discourse arose to construct a new Turkish identity on the international stage. In stark contrast to Kemalist officials who viewed EU membership as a 'natural requisite of the Republic's policy of joining the Western civilization', AKP ministers now spoke openly of Turkey's distinct culture and its unique position as a hybrid nation straddling European and Asian civilizations. ${ }^{17}$ Turkey now became imagined - in the words of former President Gül - as a 'Eurasian country that bridges the East and the West'. Furthermore, (then) Foreign Minister Davutoğlu and other AKP ministers emphasised that Turkey is a 'central country with multiple regional identities that cannot be reduced to one, unified character'.$^{18}$ Additionally, Davutoğlu stressed that Turkey 'should be in the centre of the table where the new global order is formed'. ${ }^{19}$ The Turkish nation - in this elite imagination - thereby asserted itself as an independent and unique global actor, one not necessarily encumbered by, or aligned to, the European metropole. Such language underscored the dignity and autonomy of the Turkish nation, in the aftermath of stalled EU negotiations.

Crucially, AKP officials in this re-orientation embraced the historical memories of (neo)Ottomanism. This followed the example of the Özal government and its attempts in the 1990s to reassert Turkish influence in the Balkans and the Middle East. After stalled EU negotiations, the Erdoğan administration began to mirror the language of this earlier Özal period. Notably, Davutoğlu acted as a 'second-wave' architect of this mode of Turkish political identity. ${ }^{20}$ Indeed, he reportedly remarked that 'they call us neo-Ottomans. Yes, we are neo-Ottomans'. ${ }^{21}$ Moreover, as Birdal emphasises, Davutoğlu argued that Turkey should take advantage of its 'strategic depth'. ${ }^{22}$ Namely, that it should take advantage not merely of its geopolitical position between the European and Asian continents, but that it should tap its unique Ottoman history as a potential power resource. In this light, Davutoğlu viewed the Kemalist 'republican break with the Ottoman past and the subsequent Westernisation process' as a source of 'ontological insecurity and alienation' among the Turkish elite. ${ }^{23}$

Importantly, this neo-Ottomanism has been embraced by the wider AKP and its core constituents. Notably, it has received enthusiastic support from Prime Minister, now President, Erdoğan. This has not only taken the form of Erdoğan's official speeches. But it has additionally taken the form of his promotion of a 'banal' neo-Ottomanism in terms of architectural design, 'daily routines', and 'printed and visual media' within his self-proclaimed 'New Turkey'. ${ }^{24}$ This has helped to cement internal support for the government. Moreover, Erdoğan in his promotion of this neo-Ottoman Turkey "has... [also] demonstrated his readiness to "abuse" Europe... in his determination to cement the bond between himself and his core domestic political constituency'. ${ }^{25}$ 
It is necessary to emphasise, however, that this neo-Ottoman turn is not merely a nationalist project. It is a wholly normative enterprise that articulates an explicit moralism in terms of the character of the Turkish nation. Notably, (then) Foreign Minister Davutoğlu and (then) President Gül took a leading role in the articulation of this ethical face:

Foreign Minister Davutoğlu has started to describe the 'ethics' underpinning Turkey's foreign policy framework as being sincere, honest, transparent, trustworthy, neutral, hopeful, inclusive and sharing a common vision. President Gül has also stated that Turkey's framework emphasises human dignity and justice, serving as a unique and 'virtuous power'. ${ }^{26}$

Significantly in terms of Turkish relations with the Global South, moreover, AKP leaders have stressed that the Ottoman Empire never engaged in the fully fledged 'colonialism' of European powers. The relationship between the Ottoman centre and its peripheral zones is instead seen to have been one of consent, anchored by cultural ties between fellow Muslims as part of a 'pax-Ottomana'. ${ }^{27}$ In the modern era, therefore, the neo-Ottoman identity is presented as a benevolent force in the Global

South in contrast to Western hegemony, within an 'anti-colonial' narrative. ${ }^{28}$ Moreover, the neoOttoman discourse emphasises that Turkey as an emerging economy is willing to demonstrate its friendship in a material sense, namely via beneficial aid and trade linkages with poorer countries. Turkey promises in this neo-Ottoman phase to utilise soft power instruments (such as aid) to improve the lives of neighbouring, and distant, peoples.

In this context that there has been an explicit AKP foreign policy discourse of 'Virtuous Power Turkey' and of 'humanitarian power'. ${ }^{29}$ This clearly has parallels to scholarly debates about the socalled normative power exhibited by the EU. ${ }^{30}$ Turkey under Erdoğan now seeks to utilise its emerging economic and political status to exert positive idea-force in its dealings with other countries. Furthermore, it is clear in this context that EU officials' communications (such as those on African ties) which imply that the EU is uniquely predisposed towards a special form of normative action (as Manners once implied) fail to adequately recognise how other polities similarly draw upon history, myth and language to present an ethical foreign policy to the wider world. In the case of Turkey's neoOttomanism this seeks to legitimise a new activism in terms of trade, aid and political linkages with the former Ottoman territories, and beyond. 'Virtuous Power Turkey' - in a neo-Ottoman discursive framework - has emerged as a distinct player, with its own interests and ethical objectives, separate from the European 'other'.

As the next section demonstrates, AKP elites have in fact consciously drawn parallels between the benevolent intent of Turkey with the apparently regressive actions of Western actors. A focus on Turkish interventions in sub-Saharan Africa, in particular, helps us to examine how Erdoğan government ministers have sought to construct Turkish foreign policy identity in flattering contrast to the apparent malevolence of a hegemonic EU. Moreover, a focus on sub-Saharan Africa demonstrates how the neo-Ottoman discursive framework has resonance for global politics beyond the sphere of influence once enjoyed by the Ottoman state. Importantly, the article then examines whether Turkish interventions are necessarily 'virtuous' in terms of their tangible impact.

\section{Virtuous Power Turkey in sub-Saharan Africa: 'othering' the European Union}

While the immediate activism of the AKP in the wake of 2005 had been within the Middle East and North Africa, AKP elites soon turned to sub-Saharan Africa after the onset of the Syrian Civil War and 
the outbreak of the Somali famine during the Ramadan Festival in 2011. Turkey's worsening relationship with the Bashar al-Assad regime, and latterly with other Arab regimes (such as General elSisi's dictatorship), has done much to frustrate Turkish ambitions in its immediate neighbourhood. Accordingly, elites have increasingly emphasised sub-Saharan Africa as a region in which the Turkish nation may put its neo-Ottoman ideals into practice. Dealing with poorer countries such as Somalia will apparently enhance the reputation of Turkey as an influential and independent actor on the global stage. It will also be a means of tangibly demonstrating the altruism of the AKP government, and more broadly, of the Turkish people themselves.

Interestingly, AKP elites' construction of this foreign policy role in sub-Saharan Africa has drawn sharp contrasts between Turkey and Western actors, particularly the EU. Notably, Davutoğlu has sought to emphasise the anti-colonial credentials of the neo-Ottoman foreign policy:

Stretching hundreds of years back, our history tells us that the wellbeing of Africa and Turkey cannot be separated from each other. Within a relationship based on equality, mutual respect, cooperation and common stance against adversaries, the rise of African and Turkish civilizations were always closely linked ... when our ties and defences were weakened due to many reasons including imperialism, colonialism, conflicts or inner strife, we were both weakened and fell back behind other nations.

Going further, Davutoğlu has made clear that Turks and Africans share a similar culture, underpinned by the Ottoman state's historical influence. He states that 'we are proud of this... culturally we see ourselves as African'. ${ }^{31}$ Davutoğlu further claims that the 'the great powers' are dismayed that Turks should 'even go to Africa', since it strikes at their own influence and hegemony in the region. ${ }^{32}$

This defiant discourse has been mirrored by (then) President Gül. With parallels to Davutoğlu, an anti-colonial - and indeed, arguably anti-European tone is struck:

We [Turks] have never run after only our own interests. We know that states, which only looked after their own interests in the past engendered major damage to Africa. The international community should know that we could only be equal partners in Africa. ${ }^{33}$

This implicit denunciation of Western imperialism has been augmented by Gül with more direct language. Speaking to Ghanaian officials, the former President of Turkey made clear that:

We are different from Europeans. We do not take away your raw materials. We invest and also bring along technology and qualified workforce. We have done so in other African countries. We have already begun to do so in Ghana as well. ${ }^{34}$

Gül has also referred to Turkey's intent to bring a 'clean slate with a humanist approach' in its dealings with African countries, again alluding to the murkier histories of other (Western) powers in their own relations with the region. ${ }^{35}$

Interestingly this anti-colonial, anti-European tone has filtered down to Turkish business, media and civil society. An influential article in Insight Turkey by Abdirahman Ali, for example, lavished praised upon the Erdoğan government for its humanitarian intervention in Somalia. Ali made clear that the altruism of Turkey marked a clear contrast from the machinations of Western powers:

Turkey's approach is a radical contrast to the security-driven approach of the US and is also very different from the strings-attached European style... The Turkish model on the 
other hand, is groundbreaking and fundamentally centrist, in that it avoids the imperialist tendencies of the US and Europe, all the while establishing "a moral" standard anchored in protecting human rights and helping the weak. ${ }^{36}$

This anti-Western perspective is even underlined in the statements of Turkish business entrepreneurs, demonstrating the 'common sense' nature of the 'virtuous' neo-Ottoman foreign policy:

Somalis do not want Western companies in their markets. They think, 'our problems started because of America and other countries'. They want to continue without America and the other countries. ${ }^{37}$

Given the origins of the neo-Ottoman turn in the wake of stalled EU accession, this particular theme is of much interest. Emphasis on the benevolence of Turkey plays a double role. It legitimises Turkish foreign policy intervention on the basis of its enlightened nature - that is to promote 'win-win' cooperation among equals. Second, it does much to delegitimise the EU's role in the region (opening up greater space for Turkish action) as well as distancing Turkey from the need to join such an 'imperial' entity. In this way, AKP elites not merely open up opportunities for trade and aid linkages in subSaharan Africa. But they also assuage domestic opinion on the issue of (stalled) EU membership, and thereby challenge European elites themselves both to rethink their conduct towards Turkey, and to Africans. Indeed, within the utterances of AKP officials there is the distinct implication that Turkey itself has been the 'victim' of EU policies in the past. Turkey and Africa, standing together, are seen as a solid bloc able to warn off encroachments from possible imperial powers, such as the EU.

Significantly, however, this negative tone is balanced by more positive themes. In particular, there is emphasis on the ability of Turkey to develop friendly relations with African states that are home to significant Muslim populations. The past role of the Ottoman Empire as the seat of the Caliphate, and its subsequent influence on the development of the Islamic world, is positively invoked. Notably, Turkey has enhanced its role within the Organization for Islamic Conference, inviting African dignitaries to take part. ${ }^{38}$ Additionally, Turkish elites have emphasised the development mission of the Turkish state via the Turkish Co-operation and Co-ordination Agency (TIKA). Turkish assistance is emphasised as having increased dramatically in the period of the Erdoğan governments. A TIKA report from 2013, for instance, remarks that Turkish overseas aid rose from $\$ 85$ million in 2002 to $\$ 3.3$ billion in 2013. In terms of African countries, Turkish aid has reached substantial proportions, standing at $\$ 749.47$ million in 2012 and $\$ 782.73$ in $2013 .{ }^{39}$ This is matched by increases in terms of Turkish trade with sub-Saharan Africa, which 'reached $\$ 7.5$ billion in 2011, a 72 percent increase from the year before and a tenfold increase since $2000^{\prime} .{ }^{40}$ It is also augmented by the expansion of Turkish embassies throughout the region, as well as an increase in the number of aviation routes to Africa from Turkey. ${ }^{41}$

Crucially, Turkey has utilised interventions in Somalia as a 'showpiece' for its potential humanitarian clout throughout sub-Saharan Africa. In the wake of the 2011 famine, the Erdoğan government sought to demonstrate the potency of its more assertive neo-Ottoman stance. This emphasised the normative values of Virtuous Power Turkey in juxtaposition with the perceived neglect of Somalia by self-interested Western entities. It also underscored the material capabilities of Turkey as an emerging economy, tangibly demonstrated in terms of aid and trade assistance. A visit to the war-torn nation by Erdoğan himself in 2011 was a particular highlight. It at once demonstrated the ability of Turks to take advantage of cultural affinity to offer friendship to (Muslim) peoples in Africa. It also underlined the apparent ethical qualities of the leader, as well as of the Turkish state. 
Significantly this intervention has also been utilised to reinforce the neo-Ottoman theme that Turkey is a virtuous power in contrast to the West, and the EU institutions. Erdoğan took the opportunity in a UN General Assembly Address to highlight colonialism as the historical foundation of Somalia's recent plight:

We should not only look into the picture of today, but also the shameful history that has led Somalia into the arms of this great tragedy. Indeed, beneath the tip of this huge iceberg lie great crimes against humanity. In that respect the situation in Somalia has also revealed the deep wounds inflicted by the colonialist mentality which kept Africa under its hegemony for centuries. As this old colonial mentality ignores places where it has no interest, it is now watching millions of children die in need of a morsel of bread. ${ }^{42}$

Importantly, this discourse was materially buttressed by TIKA aid, private donations, as well as trade. Private Turkish donations to Somalia alone amounted to more than $\$ 365$ million in $2011 .{ }^{43}$ Moreover, by 2014, the Turkish state had delivered around $\$ 500$ million in aid. ${ }^{44}$ 'Virtuous Power Turkey' also extended 1200 scholarships to Somali youth as a means of building in concern for that country's longer-term progress. ${ }^{45}$ Interestingly, narratives of the activism of the Turkish state were also matched by language pertaining to the activism (and heroism) of Turkish aid workers and NGOs. Again, humanitarian action on the part of Turkish citizens was contrasted by AKP elites with the perceived inaction of EU officials who maintained headquarters in the distant Kenyan capital, Nairobi. Most striking, however, this discourse was repeated by Somali leaders. Notably the President of Somalia juxtaposed the humanitarianism of the Turks with the uncaring attitude of 'other powers':

Turkey did not hold back, waiting for stability before it invested... where other international partners chose to plan their interventions from elsewhere [such as the EU based in Nairobi], Turkey put its people on the ground in Somalia. ${ }^{46}$

Interestingly, the Somali government has also endorsed the historical image of a benevolent Ottoman Empire. For instance, the Somali President recently welcomed Erdoğan back to the country in 2015, noting that 'the friendship between Turkey and Somalia is long - beginning in the $16^{\text {th }}$ Century with ties between the Ottoman Empire and the Abel Sultanate' ${ }^{47}$

It is important to restate, however, that Turkey does not intend to limit itself to partnership with this one African country. Already, Turkish embassies have made strategic linkages with African officials beyond the Horn of Africa. Moreover, President Gül made trade and aid objectives known to his Ghanaian counterparts in the West of Africa. More recently, President Erdoğan has engaged East African countries as part of a 2016 tour. Turkey - in its neo-Ottoman phase of assertive, humanitarian diplomacy- is giving largesse to Somalia as a means of launching a wider African policy. As Harte states 'with its unrivalled on-the-ground rebuilding effort and generous scholarship program, Turkey is using Somalia as the first great display of "virtuous power"'. ${ }^{48}$

Furthermore, AKP elites envisage a sustained Turkish challenge to a wider 'world-system' dominated by the EU and other Western powers. ${ }^{49}$ Turkey is thus portrayed as a great emerging 'MINT" power of its own accord. Specifically, Virtuous Power Turkey seeks to 'put the traditional world on notice' and to challenge regressive forms of Western, and EU, interventions in the Global South (Ali 2011: 65). It is important, however, to contextualise Turkish constructs in terms of consequences for African citizens, as well as for Europe's international actorness. The next section therefore, considers, whether Turkish claims to promote humanitarian aid and trade linkages in Africa should be tempered. 
Moreover, it explores consequences for the EU given the manner in which it has been so fiercely contrasted with the apparent 'virtuous' nature of Turkish foreign policy.

\section{Whither African development? Whither EU-Africa ties?}

As explored above, a constructivist perspective when allied to critical discourse analysis may challenge power asymmetries that are either veiled, or downplayed, through language. ${ }^{50}$ Accordingly, it is important to question whether there might be disjuncture between stated Turkish objectives and material policy outcomes. This is not to deny the contributions of Turkish aid in wake of famine. But it is to question whether there may be negative repercussions of particular forms of Turkish interventions that are hidden, or rationalised, by dominant forms of neo-Ottoman policy discourse. In particular, it is notable that Turkish elites have spoken of their intent to provide assistance as a precursor to enhanced business linkages in Somalia, and beyond. ${ }^{51}$ The stabilisation of Somalia is understood as a form of enlightened altruism in which the Turkish benefactor will gain trading access to an important regional hub. ${ }^{52}$ As such, Somalia is understood as a staging post for greater Turkish economic involvement in sub-Saharan Africa. Note for example (then) President Gül's visit to Ghana. Moreover, the Turkish government has made clear its intent to 'double its trade volume with all African countries, currently at $\$ 16$ billion in a "few years". ${ }^{53}$

Specifically, there are grounds on which to doubt whether Turkish foreign direct investment will necessarily have positive consequences for ordinary workers and communities. For example, in Somalia there has been recent condemnation of Turkish investment in ports facilities. Workers have protested local job losses amidst the arrival of Turkish managerial class to operate the facilities in a more 'professional' manner. Also there is concern that Turkish investors will use imported machinery to the detriment of local peoples. In the words of one port worker:

the [Somali] government deliberately handed over the port to the Turkish company without considering our right to work and earn an income... Turkey wants to use its lifts instead of the thousands of porters. ${ }^{54}$

Moreover, there are those (not least the terror group, Al Shabab) who question Turkish motives in terms of oil reserves within Somalia's Puntland province. There is general recognition that Turkey, as a MINT emerging economy, has geopolitical interest in Puntland to deliver energy security. The province could produce 10 billion barrels of oil, while Turkey currently imports around 600,000 barrels per day. ${ }^{55}$ There are thus concerns about Somalia's loss of a vital resource, environmental degradation, as well as the likely treatment of Somali workers by Turkish energy companies. Incidents such as the 2014 mining disaster in Soma and the lack of protection of Turkish workers' rights increase fears that Turkish foreign direct investment may not entail progressive results for poorer workers in Somalia.

Significantly, concerns about Turkey's motives in the region are not confined to Somalia. As Özkan and Orakçi remark of officials in sub-Saharan Africa more widely:

Some view Turkey as concerned mostly with its own economy and industries, and many associate Turkey with a self-interested approach to trade. For this reason, many African countries have been suspicious of Ankara's manoeuvres over the past decade. ${ }^{56}$

There is also wider concern about the impact of Turkish aid policy in terms of exacerbating 'corrupt' government. Notably, the decision of the Turkish government and TIKA to give monies to recipients 
without following Western reporting protocols potentially lends itself to the subsidisation of Somali (and wider African) elites without due anti-graft measures. ${ }^{57}$ This is amplified by the fact that - as demonstrated above - certain African personnel have engaged in deliberate 'extraversion' ${ }^{58}$ That is, they have made deliberate appeals to external donors as a means of lubricating domestic patronage networks. In the case of Turkey, Somali officials have deliberately complimented the humanitarian selfimage of AKP elites as a means of levering in greater aid flows from their benefactors in Ankara. As Murphy and Woods remark 'Somalis [in government institutions] have played the development game a long time, and they know how to play it well'. ${ }^{59}$ Accordingly, there is the fear that 'naïve' Turkish officials are lubricating the patronage networks of the Somali government without due concern for corruption issues.

Additionally, there is concern that Turkey is merely following the EU (and the 'BRICS') in a 'new scramble' for African markets. Notably, Turkish elites are vigorously pursuing free trade agreements (FTAs) with African countries including the Democratic Republic of the Congo (DRC), Seychelles, and Cameroon. ${ }^{60}$ Meanwhile, a recently signed a FTA with Mauritius is partially based upon the EU's own interim Economic Partnership Agreement (EPA) with this African nation. ${ }^{61}$ This FTA will likely prove a boon to Turkish entrepreneurs, but will pose a serious challenge to local business people who will have to compete with (often) cheaper foreign manufactures. Turkey is thus seen to follow a mercantilist instinct, one which may 'kick-away-the-ladder' of development by depressing domestic entrepreneurial growth in sub-Saharan Africa. Rather than depart from the machinations of an 'imperial' EU (or of rival BRIC nations), Turkey is instead seen as yet one more player in the new scramble for African markets.

Perhaps most alarmingly, there is also concern about the provision of Turkish arms to African countries. In the case of Somalia, the Turkish state signed a 2014 agreement to build fully equipped military bases, and to train government forces. ${ }^{62}$ In terms of sub-Saharan Africa more broadly, Turkish military firms Aselsan and Turkish Aerospace Industries have seen impressive revenue gains. Aselsan's revenues grew from around $\$ 800$ million in 2012 to approximately $\$ 1$ billion in 2013. This was coupled to rising revenues for Turkish Aerospace Industries which increased from around \$650 million in 2012 to just under $\$ 800$ million in $2013 .{ }^{63}$ Such trends not only raise alarm in terms of the support of African governments with dubious human rights records. They also raise questions in terms of Turkish arms falling into the possession of radical militias, whether deliberately, or accidentally through capture of state equipment. In the case of Syria there has already been widespread allegation that AKP elites consciously supported ISIS forces as a means of destabilising their erstwhile ally, Bashar al-Assad.

In the African context there are in fact parallel concerns expressed by secular civil society activists that AKP elites are embroiling themselves in similar civil conflicts. Altintas notes that there are 'harrowing claim[s] that Turkey has armed jihadist groups in Nigeria', namely Boko Haram. ${ }^{64}$ In this Nigerian context, there are specific allegations that Turkish Airlines has been forced to channel arms, despite the apparent protestations of its managerial echelons. ${ }^{65} \mathrm{It}$ is also interesting to note that the Turkish ambassador to Chad, Ahmet Kavas, publicly expressed his reservations about French action in neighbouring Mali in 2014 to tackle al Qaeda in the Islamic Maghreb. ${ }^{66}$ Fears have been raised that Turkish armaments have fuelled Islamist insurgencies in Chad and Mali, in addition to the cases of Nigeria and Syria. The creeping militarisation of Africa via Turkish defence firms - whether in terms of arms to de jure states, or to radical Islamist groups - is a clear cause for concern and does much to undermine the apparent 'ethical' tone of Turkish foreign policy. 
Moreover, at an ideational level there is concern that Turkish interventions might perpetuate power asymmetries. In particular, Turkish aid-giving might reinforce a (paradoxical) Orientalism exhibited on the part of AKP elites, and within the wider Turkish population. Indeed, there is already a perception in certain quarters of Turkish society that African states are 'weak' and are 'embarrassingly incompetent'. ${ }^{67}$ Moreover, 'Sub-Saharan Africa has been perceived to be a distant and unfamiliar area with a variety of problems such as hunger, civil wars and disaster' ${ }^{68}$ In this context, the policy reports of bodies such as TIKA may perpetuate an Orientalist gaze. The opening quote of this article from Erdoğan underlines that there is a tendency for AKP narratives to portray their state as the humanitarian 'saviour' of weaker polities. At the level of post-colonial imaginaries, this element of AKP discourse threatens to perpetuate stereotypes of African nations as tragic containers of human misery. This does much to impinge upon African agency - further marginalising African states on the international stage. Following Edward Said, it leaves African societies vulnerable to regressive forms of external intervention on the grounds of their implied 'barbarity' or lack of capability. ${ }^{69}$

Furthermore, there are major implications of the neo-Ottoman entry into sub-Saharan Africa for the European project itself. As explained, AKP elites have deliberately drawn upon colonial histories to portray Europe (perhaps rather convincingly) as a neo-colonial entity concerned solely with resource extraction, or trading interests. Turkey as an emerging power with a benevolent Ottoman heritage, on the other hand, has been portrayed as a culturally compatible friend that seeks to counter European hegemony. In fact there is a potential paradox in Turkish discourse here as the EU is simultaneously condemned for its neo-colonial incursions in Africa, while also being condemned for being too remote in cases such as Somalia. Nevertheless, Turkish elites counter that the EU involves itself only when its neo-colonial interests will be served. When certain countries are too unstable, then these countries are left to suffer humanitarian crises whose very origins can be traced back to European colonialism. ${ }^{70}$

'Neo-Ottomanism' thus has clear repercussions in terms of the ability of the EU to project its ideals (and interests). The emergence of 'Virtuous Power Turkey' is a clear challenge to EU-Africa trade and development ties. This might be dismissed by certain European officials as mere hyperbole stemming from AKP elites' frustration with stalled accession talks. Nevertheless, there is a real jeopardy for the EU that these confrontational, anti-colonial narratives gain wider traction within African governments, particularly in 'moderate' states such as Ghana which have heretofore largely cooperated (and acquiesced) to EU policy preferences (for instance, on the issue of Economic Partnership Agreements). While there is not sufficient scope to go into detail on the issue of EU activities in Africa within this discussion, nevertheless, there is substantial evidence which lends credence to the neo-Ottoman thesis that EU institutions are perpetuating poverty in certain African states through regressive aid and trade linkages. The role of the European Investment Bank (EIB), for instance, has been roundly condemned for environmentally and socially damaging activities in countries such as the DRC, Zambia and Mozambique. ${ }^{71}$ Moreover, the role of EU budget support has been seen to sway African officials towards disadvantageous free trade agreements. ${ }^{72}$ Accordingly, Turkish language relating to European neo-colonialism may fall upon fertile soil. African governments - offered material and discursive support from Ankara - may increasing concur with neo-Ottoman sentiments that 'Europe only thinks of itself; its aim is to exploit other countries. We should not expect help from Europe and we have to awaken ourselves'. ${ }^{73}$ 


\section{Conclusion}

Neo-Ottomanism clearly poses questions for Africans, Europeans, and for Turks. European officials would do well to reflect on the discord that unsuccessful accession has sown in their relations with AKP elites. At an ontological level, personnel within Erdoğan's governments have clearly internalised a discourse in which Europe is perceived as an aggressive and self-interested entity, with little concern for peoples outside of its borders. This bodes ill for future accession negotiations, particularly, if as AKP elites intend, Turkey is able to establish autonomous influence in its neighbourhood, and in regions such as sub-Saharan Africa. Indeed, if Turkey is able to achieve a greater international role then membership of the EU appears less of a pivotal objective. This should be of concern to the EU, as well as to Turkish opponents of AKP authoritarianism. That is, EU membership would likely help redress domestic instability engendered by the AKP. EU membership might in fact help to stabilise Turkey, notwithstanding that supranational project's own dubious engagements in sub-Saharan Africa.

Finally, the emergence of Turkey's 'virtuous power' should give pause to European officials who veer towards exceptionalism. It is clear that Turkey also views itself as having a unique moral position based on its own special history and culture. Whereas the European project emphasises its foundation in the aftermath of war and genocide, the 'neo-Ottoman' nation emphasises its moral dimensions as the successor to the 'benevolent' Ottoman Empire. Moreover, AKP elites make claims that they positively impact external partners, notably in terms of Africa, through aid-giving and trade. Turkey might therefore itself seem to be 'exceptional' in certain (AKP) circles and 'to be unique... in its explicit use of language - particularly around the meaning of "ethics" and its emphasis on working from an ethical paradigm'. ${ }^{74}$ What is clear, however, is that neither the EU nor Virtuous Power Turkey is 'unique'. A moralised foreign policy instead appears somewhat de rigeur in global politics.

\section{NOTES}

${ }^{1}$ Erdogan cited in TIKA, Turkish Development (2011), preamble

2 Langan, "Budget Support", 101-102

3 Manners, "Contradiction", 240

${ }^{4}$ ibid

${ }^{5}$ Diez "Normative Power"; Storey "Normative Power"

${ }^{6}$ Murphy and Woods, "Turkey's International"

${ }^{7}$ Aglionby et al., "The Reasons"

${ }^{8}$ Wodak "Aspects"; van Djik "Principles"; van Djik "Discourse"; Fairclough "Language"

${ }^{9}$ Rudincová "New player", 199

${ }^{10}$ Robins, "Turkey's Double", 384

11 Vera, "Neo-Ottomans"

12 cited in Aggestam, "Role Conceptions"

13 ibid

${ }^{14}$ Wodak "Aspects"; van Djik "Principles"; van Djik "Discourse"; Fairclough "Language"

${ }^{15}$ Anderson, "Imagined Communities"

${ }^{16}$ Fairclough et al, "Critical Discourse", 358

${ }^{17}$ Halerfoğlu cited in Bilgin and Bilgiç "Turkey and EU/rope", 116

${ }^{18} \mathrm{Gul}$ and Davutoglu cited in Hasimi, "Turkey's International", 133

19 cited in Harte "Turkey Shocks", 28

20 cited in Yanik, "Contesting Turkish", 84

${ }^{21}$ cited in Bilgiç and Nascimento, "Turkey's New Focus", 2

22 Birdal, "The Davutoglu Doctrine", 105

${ }^{23}$ Birdal, "The Davutoglu Doctrine", 101; Kosebalaban "Turkish Foreign", 151 
${ }^{24}$ Ongur, "Identifying", 417

${ }^{25}$ Park "Turkey's New", 163

${ }^{26}$ Murphy and Woods, "Turkey's International", 10

27 Yanik, "Contesting Turkish", 84

${ }^{28}$ Bilgiç and Nascimento, "Turkey's New Focus",

${ }^{29}$ Harte, "Turkey Shocks", 28

${ }^{30}$ Manners, "Contradiction"

${ }^{31}$ cited in Bilgiç and Nascimento "Turkey's New Focus", 2

${ }^{32}$ Hashemi, "Ottoman Response", 82

${ }^{33}$ Rudincová "New player", 199

${ }^{34} \mathrm{ibid}$

${ }^{35}$ cited in Ali, "Turkey's Foray", 66

${ }^{36}$ Ali, "Turkey's Foray", 72

${ }^{37}$ cited in Harte, "Turkey Shocks", 31, emphasis added

38 Özkan and Akgün, "Turkey's Opening", 538

39 TIKA, "Turkish Development 2012"; TIKA “Turkish Development 2013"

${ }^{40}$ Harte, "Turkey Shocks", 30

41 Özkan and Orakçi, "Viewpoints", 344

${ }^{42}$ Erdogan, "Statement"

${ }^{43}$ Harte, "Turkey Shocks", 27

${ }^{44}$ Özkan and Orakçi, "Viewpoints", 348

${ }^{45}$ Harte, "Turkey Shocks", 27

${ }^{46}$ cited in i24news.tv, Turkish President

${ }^{47}$ Radio Muqdisho, The President

${ }^{48}$ Harte, "Turkey Shocks", 28

${ }^{49}$ Haşimi, "Turkey's Humanitarian", 126-128

${ }^{50}$ Wodak "Aspects"; van Djik "Principles"; van Djik "Discourse"; Fairclough "Language"

${ }^{51}$ Kagwanja, "Turkey in Somalia"

${ }^{52}$ ibid

${ }^{53}$ Harte, "Turkey Shocks", 31

${ }^{54}$ Reuters, Somali Port

${ }^{55}$ Yurdusev Ottoman Diplomacy, 31

56 Özkan and Orakçi, "Viewpoints", 343

${ }^{57}$ Murphy and Woods, "Turkey's International, 3

${ }^{58}$ Bayart, "Politics"

${ }^{59}$ Murphy and Woods, "Turkey's International", 3

${ }^{60}$ Shinn, "Turkey's Engagement"

${ }^{61}$ The Mauritius Chamber of Commerce and Industry, "Mauritius-Turkey"

${ }^{62}$ Ryan, "Ottoman Brethren"

${ }^{63}$ Young, "Turkey is Boosting"

${ }^{64}$ Altintas, "What is Turkey"

${ }^{65}$ Rubin, "Tape Suggests"

${ }^{66}$ Kredo, "Turkish Tweet"

${ }^{67}$ Ali, "Turkey's Foray", 68

${ }^{68}$ Rudincová "New player", 201

${ }^{69}$ Said, Orientalism

${ }^{70}$ Erdogan, "Statement"

${ }^{71}$ Counter Balance, "Coherence"; Friends of the Earth, "The European"; Brynildsen and Nombora, "Mining"

72 Langan, "Budget Support"; Alvarez, "The Rise"; Wolff, "EU Budget Support"

${ }^{73}$ Şemsettin Günaltay cited in Hashemi, "Ottoman Response", 89

${ }^{74}$ Murphy and Woods, "Turkey's International", 10 


\section{Bibliography}

Aggestam, L. "Role Conceptions and the Politics of Identity in Foreign Policy". ARENA Working Papers, WP 99/8 (1999), online

Aglionby, J. and M. Srivastava and M. Fick "The Reasons Behind Turkey Leader Recep Erodgan's Africa Tour". The Financial Times, $2^{\text {nd }}$ June 2016

Ali, A. “Turkey's Foray into Africa: a New Humanitarian Power? Insight Turkey 13, no.4 (2011): 65-73

Altintas, E. B. "What is Turkey doing in Africa?". The Daily Zaman, $23^{\text {rd }}$ September 2015.

Alvarez, R. "The Rise of Budget Support in European Development Co-operation: A False Panacea". FRIDE Policy Brief 31 (2010). Madrid: FRIDE

Anderson, B. Imagined Communities. London: Verso, 2006 [1983]

Bayart, J. F. The Politics of the Belly. London: Polity, 2004

Bilgiç, A. and D. Nascimento D. Turkey's New Focus on Africa: Causes and Challenges. Oslo: NOREF, 2014

Bilgin P and A. Bilgiç "Turkey and EU/rope: discourses of inspiration/anxiety in Turkey's foreign policy". Review of European Studies 4, no.3 (2012): 111-124

Birdal, M. S. "The Davutoğlu Doctrine: the Populist Construction of the Strategic Subject" In Turkey Reformed: Constituting Neoliberal Hegemony, edited by I. Akça and A. Bekmen. London: Pluto Press, 2013

Counter Balance Coherence for Development? Development Check of the Financing Activities of the European Investment Bank. Brussels: Counter Balance, 2009.

Diez, T. “Normative Power as Hegemony". Cooperation and Conflict 48, no. 2 (2012): 194-210

Elgström O. "EU Foreign Policy as Others See It - Images of EU as an International Negotiators. Themes, Purpose and Approach". Statsvetenskoplig Tidskrift 10, no. 8 (2006): 163-172

Erdoğan R. T. "Statement by Recep Tayyip Erdoğan at $66^{\text {th }}$ UN General Assembly". Voltaire Network. New York, 22 ${ }^{\text {nd }}$ September 2011

Fairclough, N. "Language and Globalisation". Semiotica 173. no.1 (2009): 317-342

Fairclough, N. and J. Mulderrig and R. Wodak "Critical discourse analysis". In Discourse Studies: A Multidisciplinary Introduction, edited by T. A. van Djik. London: SAGE, 2009

Friends of the Earth International The European Investment Bank in the South: In Whose Interest? Amsterdam: Friends of the Earth, 2006

Harte, J. "Turkey Shocks Africa". World Policy Journal 29, no.4 (2012): 27-38

Haşimi C. "Turkey's Humanitarian Diplomacy and Development Cooperation". Insight Turkey 16. no.1 (2014): 127-145 
Hasemi, S. A. "The Ottoman Response to the Western Storm: Lessons for Neo-Ottomanism in Turkey". The Quarterly Journal of Political Studies of Islamic World 2, no.8 (2014): 81-96

Hudson, V. M. Foreign Policy Analysis. Plymouth: Rowman and Littlefield, 2014

i24news.tv Turkish President Erdoğan Visits Somalia. 26 ${ }^{\text {th }}$ January 2015

Kagwanja, C. "Turkey in Somalia: Building Relations using brotherhood, aid and dialogue". The East African. 29"h June 2013

Kösebalaban, H. Turkish Foreign Policy: Islam, Nationalism and Globalisation. London: Palgrave, 2011

Kredo, A. "Turkish Tweet Turns Heads". The Washington Free Beacon. 27 th $^{\text {th }}$ February 2013

Langan $\mathrm{M}$ "Budget support and Africa-European Union relations: Free market reform and neocolonialism?" European Journal of International Relations 21, no.11 (2015): 101-121

Manners, I. "Normative Power Europe: A Contradiction in Terms?" Journal of Common Market Studies 340, no.2 (2002): 235-58

Mauritius Chamber of Commerce and Industry Mauritius-Turkey Free Trade Agreement (FTA). Port Louis: MCCl, 2016

Murphy, T. and A. Woods "Turkey's International Development Framework - Case Study: Somalia". IPC-Mercator Policy Brief, February (2014). Istanbul: Istanbul Policy Centre, 2014

Ongur, H. O. "Identifying Ottomanisms: The Discursive Evolution of Ottomans Past in the Turkish Present". Middle Eastern Studies 51, no. 3 (2015): 416-432

Özkan' M. and B. Akgün "Turkey's Opening to Africa”. Journal of Common Market Studies 48, no.4 (2010): 525-546

Özkan M and S. Orakçi "Viewpoint: Turkey as a 'Political' Actor in Africa - an Assessment of Turkish Involvement in Somalia". Journal of Eastern African Studies 9, no. 2 (2014): 343-352

Park, B. "Turkey's New Foreign Policy: Newly Influential or Just Over-Active?" Mediterranean Politics 19, no. 2 (2014): 161-164

Radio Muqdisho, The President: 'We Welcome Our Turkish Friends Back to Somalia', $25^{\text {th }}$ January 2015

Reuters Somali Port Set for Facelift with Turkish Help. 23 ${ }^{\text {rd }}$ October 2014

Robins, P. “Turkey's 'Double Gravity' Predicament: The Foreign Policy of a Newly Activist Power". International Affairs 89, no. 2 (2013): 381-397

Rubin, M. “Tape Suggests Turkey Supports Terror". Commentary. 20 ${ }^{\text {th }}$ March 2014

Rudincová, K. "New player on the Scene: Turkish Engagement in Africa". Bulletin of Geography: Socio-economic Series 24 (2014): 197-213

Ryan, G. "Ottoman Brethren: Turkey's Role in Somalia's Recent Development". Polity.org.za. $12^{\text {th }}$ December 2014.

Said, S. Orientalism. New York: Random House, 1979 
Shinn, D. Turkey's Engagement in Sub-Saharan Africa: Shifting Alliances and Strategic Diversification. London: Chatham House, 2015

Storey, A. "Normative Power Europe? Economic Partnership Agreements and Africa". Journal of Contemporary African Studies 24, no. 3 (2006): 331-346

TIKA Turkish Development Assistance 2011. Ankara: TIKA, 2011

TIKA Turkish Development Assistance 2012. Ankara: TIKA, 2012

TIKA Turkish Development Assistance 2013. Ankara: TIKA, 2013

van Djik, T. A. Principles of critical discourse analysis. Discourse and Society 4, no. 2 (1993): 249-283

van Djik T. A. "Discourse, context, and cognition”. Discourse Studies 8, no. 1 (2006): 159-177

Vera, V. "The Neo-Ottomans: Looking East Without Looking Back". Foreign Policy Journal. June $15^{\text {th }} 2010$

Yanik, L. K. "Contesting Turkish 'Exceptionalism': Discourses of Liminality and Hybridity in PostCold War Turkish Foreign Policy". Political Geography 30 (2011): 80-89

Young, A. "Turkey is Boosting Weapons Exports with a Focus on Africa: Here's Who Benefits". ibTimes.com. $5^{\text {th }}$ August 2014

Yurdusev, A. N. Ottoman Diplomacy: Conventional or Unconventional? London: Palgrave, 2004

Washington Post "Why Turkey's President Wants to Revive the Language of the Ottoman Empire". Washington Post. $12^{\text {th }}$ December 2014

Wodak R. "Aspects of Critical Discourse Analysis". ZfAL 36 (2002): 5-31

Wolff, S. "EU Budget Support as a Transnational Policy Instrument: Above and Beyond the State?". Public Administration 93, no. 4 (2015): 922-939 